\title{
PETROLOGY AND GEOCHEMISTRY OF NOORABAD OPHIOLITE (LORESTAN PROVINCE, WEST IRAN): AN EVIDENCE OF INTRA-OCEANIC SUBDUCTION
}

\author{
Masoud KIANI, Nima NEZAFATI *, \\ Mansour VOSOUGHI ABEDINI and Ali SOLGI
}

Department of Geology and Geophysics, Islamic Azad University, Science and Research Branch, Tehran, Iran

*Corresponding author's e-mail: nima.nezafati@gmail.com

\begin{tabular}{l} 
ARTICLE INFO \\
\hline Article history: \\
Received 18 January 2020 \\
Accepted 3 August 2020 \\
Available online 24 August 2020 \\
\hline
\end{tabular}

Keywords:

Intermediate and Mafic rocks

Geochemistry

Noorabad ophiolite

Intra-oceanic subduction

\begin{abstract}
The Noorabad ophiolite is part of Kermanshah ophiolites in NW of Lorestan province, west Iran. The Kermanshah ophiolite complex with NW-SE trending is located in the SSW of the main Zagros thrust fault within the high Zagros zone. Rocks of the Noorabad ophiolite include diabases dikes, basalts lava and andesite that outcropped in the south of the Noorabad. These rocks are intensly altered and fractured that led to hydrothermal alteration and replacement of primary minerals such as pyroxene, plagioclase and opaque minerals by secondary minerals. Based on geochemical studies, the rocks of this area have tholeiitic and calc-alkaline signature. Also the plotted rock samples in geochemical discrimination diagrams, occur in island arc basalt (IAB) field. These rocks show depletion in HREE and HFSE and also are enriched in LILE and LREE. These patterns suggest that these rocks formed in intra-oceanic subduction zone. These geochemical characteristics along with comparison with other ophiolitic rocks in east Mediterranean reveal a subduction zone environment for genesis of the intermediate and mafic rocks of the Noorabad ophiolite.
\end{abstract}

\section{INTRODUCTION}

The Late Jurassic- Cretaceous ophiolites in the Tauride-Pontide (Turkey), Zagros (Iran), and Himalayan mountain belts to the east show geochemical affinities characteristic of suprasubduction zone (SSZ) environments (Pearce et al., 1981, 1984; Arvin, 1990; Robinson and Malpas, 1990; Dilek et al., 1999; Hassanipak and Ghazi, 2000; Hébert et al., 2003; Malpas et al., 2003; Parlak et al., 2006). The Late Cretaceous Zagros ophiolites are part of Mediterranean ophiolites that can be subdivided into two belts, the outer Zargos and inner Zagros ophiolite belts (Stockline, 1977). The inner ophiolite belt includes the Nain, Dehshir, Shahr-e-Babak and, Balvard-Baft ophiolites along the southern periphery of the Central Iranian block. The outer ophiolite belt with NW-SE trending including Kermanshah, Neyriz and Haji Abad-Esfandagheh ophiolites are located along the Bitlis-Zagros suture zone that connects the Mediterranean ophiolites (e.g., Troodos) to the Middle East and Asian ophiolites (e.g., Oman). In recent years, many researchers have worked in the Zagros suture zone (Ali et al., 2013; Ali and Aswad, 2013; Saccani et al., 2013; Whitechurch et al., 2013; Azizi et al., 2013; Allahyari et al., 2014; Aswad et al., 2014; Saccani et al., 2014; Shafaii Moghadam and Stern, 2015; Nouri et al., 2016; Tahmasbi et al., 2016). Generally, intermediate and mafic rocks in the eastern Mediterranean ophiolite complex represents subduction zones or Suprasubduction (SSZ) features. These intermediate and mafic rocks have tholeiites calc alkaline composition and developed as volcanic belt within the oceanic volcanic arc (island arc) in the Neo-Tethys Ocean (Pearce et al., 1981; Arvin, 1990; Robinson and Malpas, 1990; Dilek and Delaloye, 1999; Ghazi and Hassanipak, 1999; Hassanipak and Ghazi, 2000; Shafaii Moghadam and Stern, 2011; Tahmasbi et al., 2016).

The Kermanshah ophiolites are part of NeoTethys oceanic lithosphere which was obducted to over the passive margin of Arabian plate (Fig. 1). These ophiolites outcropped as sporadic exposures near to the Alashtar and Noorabad cities in the Lorestan province, Harsin, Sahneh, Kermanshah cities in the Kermanshah province and Kamyaran city in Kurdistan province (Kiani, 2011). The ophiolite rocks in the Kermanshah area are investigated but there are many unknowns concerning their geochemical features, emplacement age, tectonic setting and petrogenesis. In this study, we investigate the petrology, geochemistry and petrography of rocks including diabasic dikes, basaltic and andesites lavas of the Noorabad ophiolites.

\section{REGIONAL GEOLOGY}

The NW-SE trending Kermanshah ophiolite complex is located in the SSW of the main Zagros thrust fault within the high Zagros zone. The sequence of Kermanshah ophiolites zone from west to east 


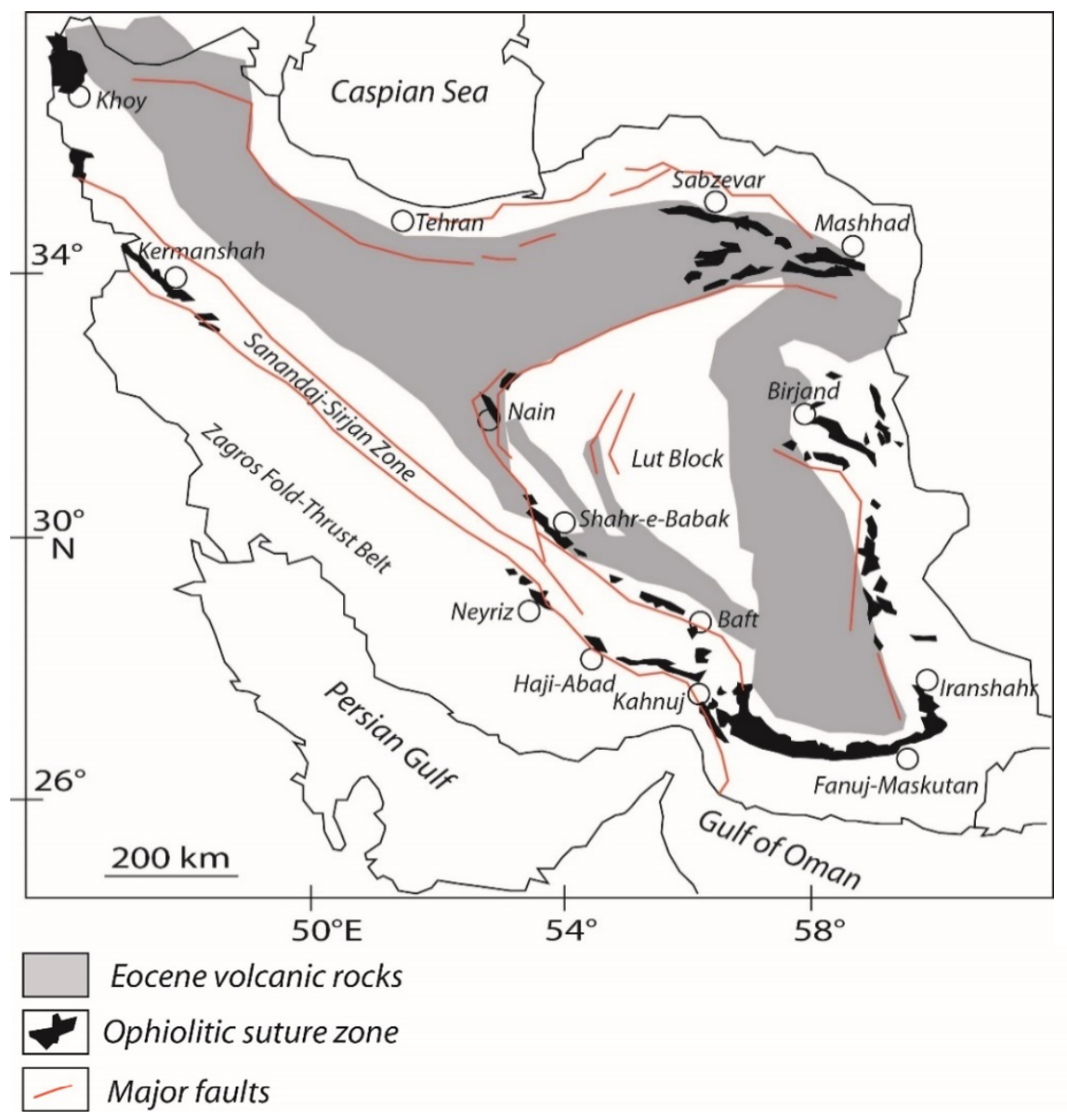

Fig.1 Map showing locations of major Iranian ophiolites (modified Stöcklin, 1968).

includes: Kermanshah radiolarites, Biseton limestone and late cretaceous Kermanshah ophiolites. The Kermanshah ophiolites contain some components of complete ophiolitic sequence including peridotite, serpentinite, pegmatite gabbro, layered gabbro, isotropic gabbro, sheeted dike complexes, pillow basalts, andesite lavas and sedimentary rocks (radiolarite and Oligomiocene pelagic limestone) (Fig. 2). This ophiolite complex covers $\sim 2400 \mathrm{~km}^{2}$ and is bounded to the north east by Sanandaj-Sirjan metamorphic rocks and to the SW by the Biston limestone, Kermanshah radiolarite and sedimentary rocks of folded and trusted Zagros zone.

The Noorabad ophiolite is part of the Kermanshah ophiolites in NW of Lorestan province, west Iran. The rocks of this ophiolite including diabasic dikes, basaltic lava and andesite. The sheeted dikes outcrop in the south of Dom Bagh village (south of Noorabad) and cover several $\mathrm{km}^{2}$ (Fig. 3A). These dikes were covered at Pliocene by conglomerate (Bakhtiyari conglomerate formation). There is basaltic lava around the sheeted dikes which intensely altered and weathered and out cropped along the fracture. In some places, sheeted dikes have outcrop with pillow lavas (Fig. 3B). They found as a small volume concentrated along western part of Dom Bagh village (Fig. 3C). Pillow lavas are intercalated and intersected by diabasic dikes (Fig. 3B). The external surfaces of the pillow lavas are characterized by calcite and $\mathrm{Fe}$ oxide filled vesicular and amygdaloidal textures. The andesitic rocks in the south of Noorabad city are extensive exposure of the andesitic rock in the Kermanshah ophiolites. They have red color in the field and alsohave fault bounded boundary with Cretaceous limestones (Fig. 3D). The andesite rocks are sheared, sliced and faulted due to the tectonic activity (Fig. 3E). The andesite rock contains elongated and rounded large plagioclase phenocrysts (Fig. 3F).

\section{ANALYTICAL METHOD}

Fifty samples from less altered diabasic dikes, basalts and andesites were selected for petrography and mineralogical studies. After petrographical observation for chemical analysis 20 fresh samples (3 samples of basaltic lavas, 5 samples of diabasic dikes and 12 samples of andesites) from South of Noorabad were analyzed for major, trace and rare earth elements (REE) by Aqua Regia Digestion at the SGS Laboratories, Canada (Tables 1 and 2). In this method, $1 \mathrm{~g}$ of the sample is dissolved in two-acid digest (a combination of $\mathrm{HNO} 3$ and $\mathrm{HCI}$ ). After the digestion, the solution is analyzed by Inductively coupled plasma mass spectrometry (ICP-MS) method. 


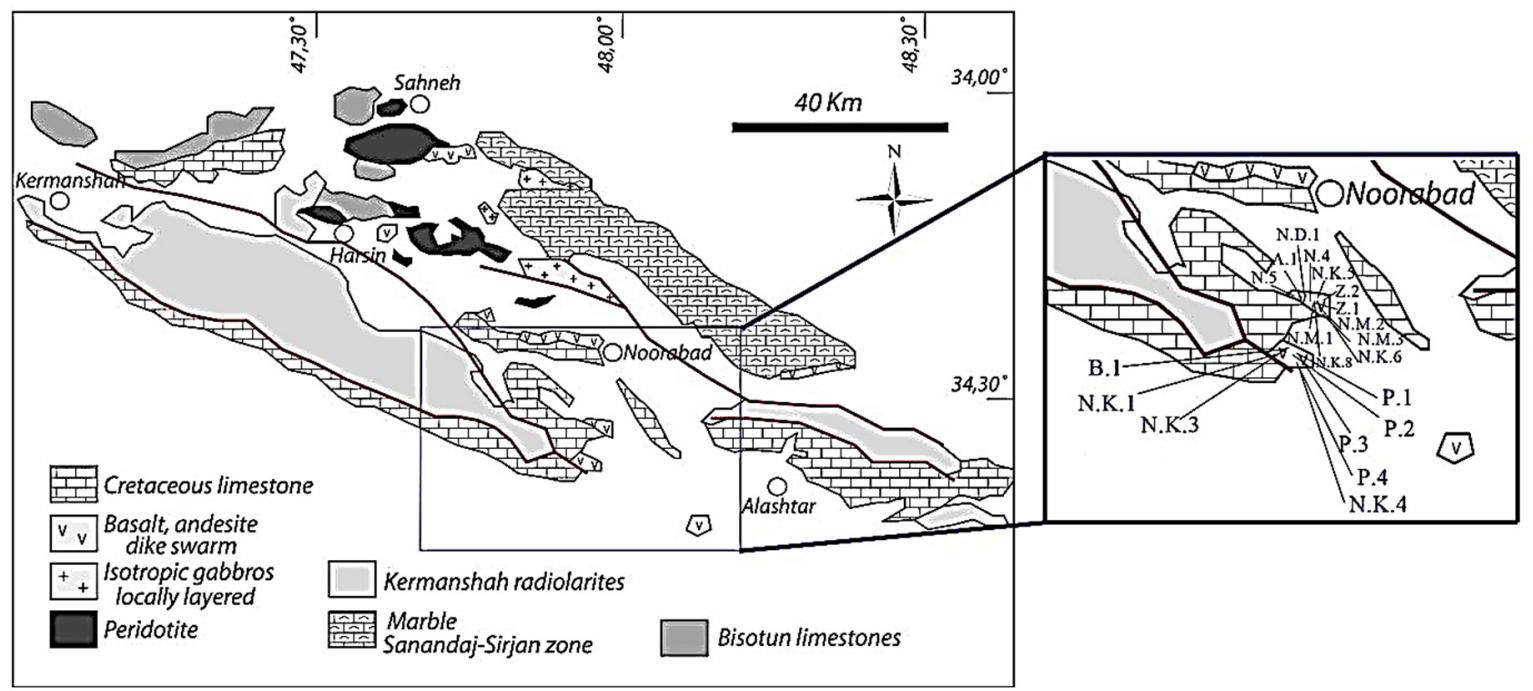

Fig.2 Simplified geological map of Kermanshah ophiolites in the Noorabad region (after Kiani, 2011). The location of samples is inside of frame.

\section{PETROGRAPHY}

In the diabasic rocks, main minerals are plagioclase, clinopyroxene and opaque minerals. Amphibole, chlorite and sericite are common accessory minerals. The main textures encountered within the diabasic rocks are doleritic, poikilitic and intergranular (Fig. 4A). Plagioclase phenocrysts are euhedral to sub-hedral and contain inclusion of pyroxene and opaque mineral. Some plagioclases have been altered to sericite. The clinopyroxene phenocrysts are enclosed by plagioclase phenocrysts and replaced to amphibole under the uralitization process.

The main textures in the basalts are intersertal, microlitic, microlitic porphyry and amygdaloid. The main rock forming minerals are plagioclase, clinopyroxene, opaque minerals while amphibole, chlorite, sericite and iron oxides are common accessory minerals. The microlite and plagioclase phenocrysts altered and replaced with sericite (Fig. 4B). The clinopyroxene grains are fine grain within the matrix. The main opaque minerals are iron oxides which along with calcite filled amygdaloide texture (Fig. 4C). The fractures and amygdals cavities in the pillow lavas filled with secondary mineral such as chlorite and calcite and have green colour in the field outcrop.

The rock forming minerals in the andesite rocks are plagioclase, clinopyroxene, opaque mineral while calcite, chlorite, zeolite, sercite, quartz and iron oxide are accessory mineral. The textures are porphyry, microlitic porphyric, glomeroporphyric and amygdaloide. The plagioclase occurs as porphyroblast and microlite which have been altered to sercite. The size of pyroxene phenocryst ranging to $2 \mathrm{~cm}$ and constitute porphyry texture in andesite rocks (Fig. 4D). The glomeroporphyritic texture is resulted from aggregation of plagioclase minerals in the cryptocrystalline matrix (Fig. 4E). The pyroxene occurs as fine crystal in the groundmass which partly altered to amphiboles and chlorite (Fig. 4F). The opaque minerals are iron oxides that along with as a secondary mineral filled cavity of andesite rocks with amygdaloidal texture.

\section{GEOCHEMISTRY}

For nomenclature and classification of studied rocks, the $\mathrm{Nb} / \mathrm{Y}$ versus $\mathrm{Zr} / \mathrm{TiO}_{2}$ diagram (Winchester and Floyd, 1977) was used. All samples plot in the andesite-basalt, andesite and rhyodacite-dacite fields (Fig. 5).

In the primitive mantle, normalized diagram, diabasic dikes represent LREE and LILE (large-ion lithophile elements) (Cs, $\mathrm{U}$ and $\mathrm{Th}$ ) enriched pattern $\left(\mathrm{Th}_{(\mathrm{n})} / \mathrm{La}_{(\mathrm{n})}=0.64-1.49\right)$ and depletion in high-fieldstrength elements (HFSE) Ti, $\mathrm{Nb}$ $\left(\mathrm{Nb}_{(\mathrm{n})} / \mathrm{La}_{(\mathrm{n})}=0.61-0.75\right)$ (Fig. 6A). The sample P.3 contains highest enrichment relative to other samples. The chonderite normalized pattern of diabasic samples are characterized by light rare-earth elements (LREE) relative to heavy rare earth elements $(\mathrm{HREE})\left(\mathrm{La}_{(\mathrm{n})} / \mathrm{Yb}_{(\mathrm{n})}=1.67-2\right)$ similar to calc-alkaline magmatism in the arc setting (Monnier et al.,1995) (Fig. 6B).

The basaltic samples show enrichments in the LILE $(\mathrm{Pb}, \mathrm{Rb}, \mathrm{K}, \mathrm{Cs}$ and $\mathrm{U})\left(\mathrm{Th}_{(\mathrm{n})} / \mathrm{La}_{(\mathrm{n})}=0.95-1.25\right)$ and relative deplation in the $\operatorname{HFSE}(\mathrm{Nb})$ $\left(\mathrm{Nb}_{(\mathrm{n})} / \mathrm{La}_{(\mathrm{n})}=0.51-0.75\right)$ in the primitive mantle normalized diagram (Fig. 7A). The N.K.1 sample show high enrichment in the elements while N.K.1 and N.K.3 represent depletion in the $\mathrm{Ba}$ and $\mathrm{Sr}$ elements, presumably, their easily movement during alteration (Fig. 7A). In the subduction related magmas, LILE concentrations is controlled by slab derived fluid and subducted sediment whilst HFSE concentrations is function of the source region melting chemistry and crystallization processes in the magma (Pearce, 1982). The negative anomaly of $\mathrm{Nb}$ and enrichment in the 

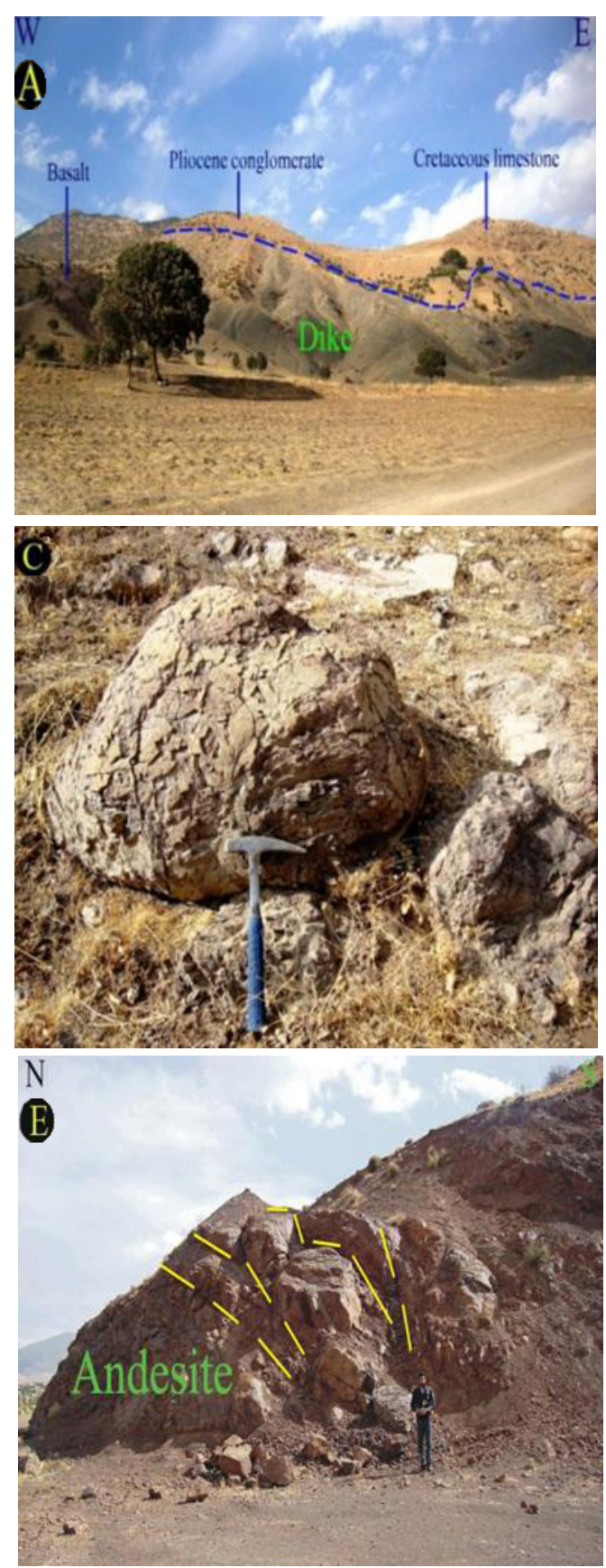
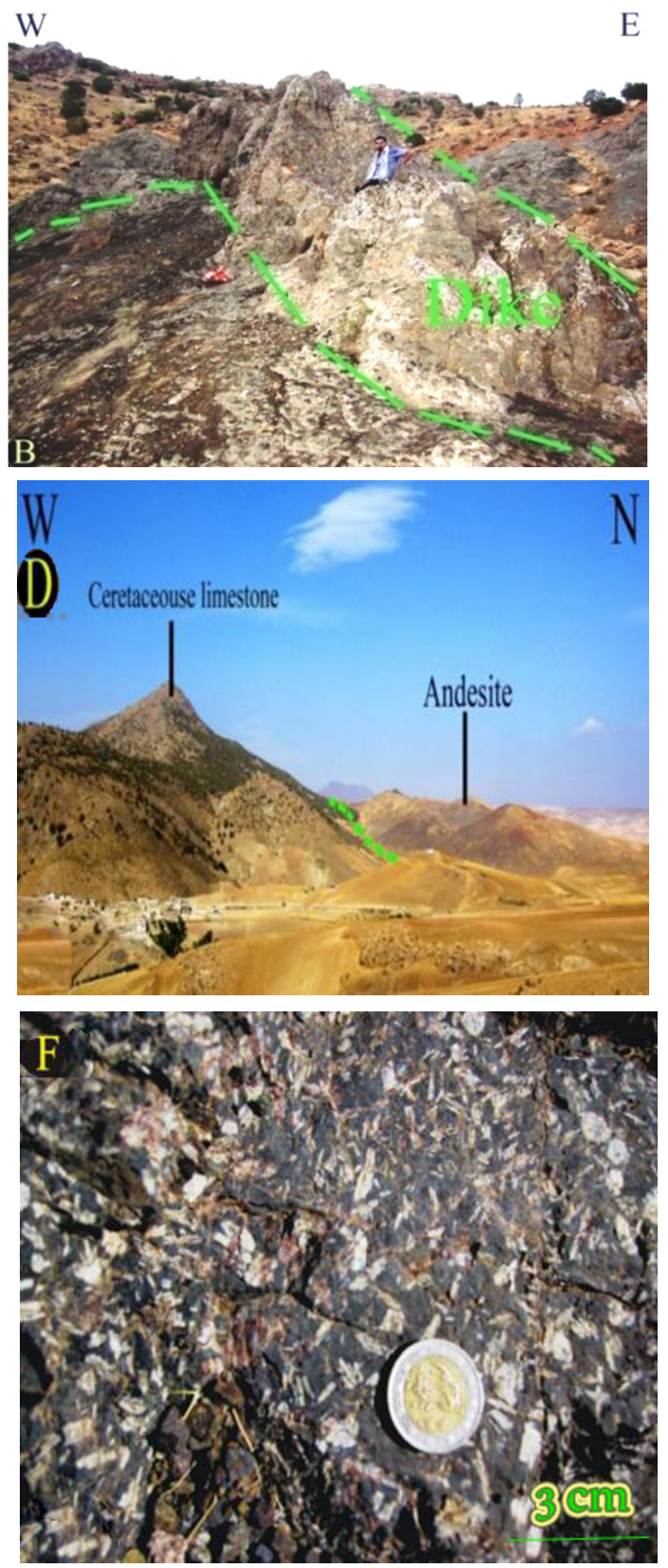

Fig. 3 Field photograph of the dikes, pillow lava and andesite rocks in the study area. A) The covering of sheeted dikes in the south of Noorabad by the Bakhtyari conglomerate formation. B) The outcrop of sheeted dikes in the southern part of the Dom Bagh village (south of Noorabad city). C) The outcrop of pillow lavas in the west of Dom Bagh village. D) Fault boundary between andesite rocks and cretaceous rocks. E) The cracking of andesite rocks due to tectonic movement. F) Phenocrysts of plagioclase in the andesite rocks.

LILE to HFSE is a characteristic feature of subduction related to arc magmatism (Gill, 1981; Shervais, 1982; Kelemen et al., 1993; Monnier, 1995; Staudigel et al., 1996; Ghazi and Hassanipak, 1999; Rolland, 2000). In the island arc magmatism, the LILE element concentrations may be function of the behaviour of fluid phases, whilst the HFSE element concentrations are controlled by source region chemistry and the crystal/melt processes (Rollinson,1993). However, $\mathrm{U}$ and $\mathrm{K}$ enrichment due to crustal contamination is plausible in the supra-subduction zone ophiolites. the basaltic lavas are characterized by enrichment of LREE and light REE (LREE) relative to heavy REE (HREE) $\quad\left(\mathrm{La}_{(\mathrm{n})} / \mathrm{Yb}_{(\mathrm{n})}=1.64-2.44\right) \quad$ (Fig. 7B) which confirms magma production in the subduction zone. The REE trend of studied basalts is similar to basaltic rocks in the Neyriz ophiolite (Sarkarinejad, 1994), the calc-alkaline lava in the Nain-Baft ophiolites (Shafaii Moghadam et al., 2009), basaltic rocks in the Kermanshah ophiolites (Shafaii Moghadam and Stern, 
Table 1 Whole-rock major, trace and Rare Earth Element (REE) analyses of representative rock samples from the andesite rocks. Major (wt.\%) and trace element (ppm) compositions.

\begin{tabular}{|c|c|c|c|c|c|c|c|c|c|c|c|c|}
\hline Sample & N.5 & A.1 & N.D.1 & N.4 & N.K.5 & N.K.6 & N.K.8 & N.M.1 & N.M.2 & N.M.3 & Z.1 & Z.2 \\
\hline $\begin{array}{l}\mathrm{SiO}_{2} \\
(\% w t)\end{array}$ & 48.3 & 50.6 & 47.8 & 45.8 & 49.9 & 46.4 & 51.7 & 54.6 & 56 & 59.3 & 53.4 & 39.8 \\
\hline $\mathrm{TiO}_{2}$ & 2.14 & 1.18 & 0.27 & 2.09 & 2.48 & 1.74 & 1.48 & 1.89 & 1.95 & 1.26 & 1.9 & 1.78 \\
\hline $\mathrm{Al}_{2} \mathrm{O}_{3}$ & 17.3 & 16.8 & 8.43 & 16.6 & 19 & 18.1 & 17 & 14.1 & 14.9 & 17 & 15.1 & 14.6 \\
\hline $\mathrm{Fe}_{2} \mathrm{O}_{3}$ & 9.81 & 8.02 & 3.12 & 9.09 & 8.72 & 7.96 & 8.14 & 7.23 & 8.37 & 4.51 & 7.47 & 20.8 \\
\hline $\mathrm{Cr}_{2} \mathrm{O}_{3}$ & 0.01 & 0.01 & 0.01 & 0.01 & 0.01 & 0.01 & 0.01 & 0.01 & 0.01 & 0.01 & 0.01 & 0.01 \\
\hline MnO & 0.1 & 0.11 & 0.28 & 0.11 & 0.04 & 0.1 & 0.1 & 0.09 & 0.07 & 0.07 & 0.11 & 0.08 \\
\hline MgO & 3.55 & 0.88 & 3.03 & 3.6 & 2.26 & 4.58 & 1.82 & 1.24 & 1.77 & 0.72 & 1.87 & 3.79 \\
\hline $\mathrm{CaO}$ & 8.49 & 7.45 & 18.9 & 9.49 & 3.65 & 6.28 & 7 & 6.99 & 4.86 & 4.3 & 6.63 & 5.58 \\
\hline $\mathrm{Na}_{2} \mathrm{O}$ & 3.80 & 7.4 & 1.8 & 3.9 & 5.2 & 5.3 & 5.3 & 6.4 & 6.4 & 7.8 & 5.6 & 5.2 \\
\hline $\mathrm{K}_{2} \mathrm{O}$ & 0.39 & 1.18 & 1.05 & 0.68 & 3.21 & 0.94 & 1.29 & 0.49 & 0.45 & 1 & 1.06 & 0.11 \\
\hline $\mathrm{P}_{2} \mathrm{O}_{5}$ & 0.36 & 0.24 & 0.08 & 0.35 & 0.52 & 0.33 & 0.3 & 0.49 & 0.52 & 0.25 & 0.4 & 0.60 \\
\hline LOI & 6.55 & 6.08 & 16.6 & 8.35 & 5.31 & 8.68 & 6.70 & 5.56 & 4.18 & 4.09 & 6.3 & 7.08 \\
\hline Total & 100.7 & 100 & 101.3 & 100 & 100.4 & 100.4 & 100.8 & 99.1 & 99.4 & 100.3 & 99.9 & 99.4 \\
\hline $\begin{array}{l}\text { Ba } \\
(\mathrm{ppm})\end{array}$ & 40 & 80 & 40 & 40 & 60 & 60 & 60 & 30 & 30 & 40 & 30 & 40 \\
\hline $\mathrm{Sr}$ & 200 & 170 & 120 & 140 & 100 & 120 & 150 & 80 & 80 & 70 & 90 & 60 \\
\hline $\mathbf{Y}$ & 30 & 30 & 30 & 30 & 50 & 30 & 30 & 40 & 40 & 20 & 40 & 60 \\
\hline Zn & 96 & 79 & 27 & 50 & 19 & 62 & 23 & 19 & 22 & 14 & 19 & 47 \\
\hline $\mathbf{Z r}$ & 203 & 126 & 165 & 190 & 310 & 195 & 216 & 227 & 240 & 154 & 217 & 242 \\
\hline Ag & 1 & 1 & & 1 & 1 & 1 & 1 & 1 & 1 & 1 & 1 & 7 \\
\hline $\mathrm{Ce}$ & 38.8 & 31.4 & 38.9 & 39.5 & 72.10 & 39.3 & 44.3 & 34.6 & 32 & 29.7 & 38.1 & 44.6 \\
\hline Co & 27.2 & 7.8 & 5.4 & 26.7 & 10 & 37.4 & 19 & 10.8 & 16.7 & 7.2 & 9.4 & 26.6 \\
\hline Cs & 0.6 & 0.5 & 1 & 0.5 & 3.7 & 0.7 & 1 & 0.05 & 0.5 & 0.9 & 1.6 & 1 \\
\hline $\mathrm{Cu}$ & 55 & 16 & 5 & 19 & 19 & 19 & 33 & 4500 & 6900 & 3680 & 57 & 46 \\
\hline Dy & 6.29 & 4.64 & 4.02 & 6.25 & 8.82 & 5.79 & 5.53 & 6.55 & 6.71 & 4.22 & 6.73 & 9.86 \\
\hline Er & 3.72 & 2.99 & 2.56 & 3.55 & 5 & 3.46 & 3.4 & 3.82 & 4.1 & 2.4 & 3.78 & 5.89 \\
\hline $\mathbf{E u}$ & 1.8 & 1.1 & 1.11 & 1.79 & 2.17 & 1.43 & 1.41 & 1.96 & 1.75 & 1.18 & 1.89 & 2.36 \\
\hline Ga & 20 & 14 & 9 & 18 & 24 & 18 & 18 & 13 & 15 & 14 & 18 & 18 \\
\hline Gd & 6.45 & 4.38 & 4.5 & 6.07 & 9.22 & 5.99 & 6.07 & 6.86 & 6.85 & 4.01 & 7.08 & 9.86 \\
\hline Hf & 5 & 3 & 4 & 5 & 8 & 5 & 5 & 6 & 6 & 4 & 5 & 6 \\
\hline Ho & 1.31 & 1.03 & 0.84 & 1.27 & 1.82 & 1.19 & 1.17 & 1.34 & 1.37 & 0.89 & 1.32 & 2.09 \\
\hline La & 16.6 & 14.7 & 18.8 & 18 & 32.9 & 17.9 & 21.4 & 15.30 & 14.1 & 14.8 & 16 & 18.7 \\
\hline $\mathbf{L u}$ & 0.53 & 0.4 & 0.41 & 0.56 & 0.77 & 0.57 & 0.52 & 0.53 & 0.59 & 0.4 & 0.53 & 0.96 \\
\hline Mo & 2 & 2 & 2 & 2 & 2 & 2 & 2 & 2 & 2 & 2. & 2 & 2 \\
\hline $\mathbf{N b}$ & 9 & 8 & 8 & 9 & 14 & 9 & 11 & 11 & 11 & 6 & 11 & 10 \\
\hline Nd & 21.5 & 15.2 & 17.4 & 21.7 & 38.1 & 21.7 & 21.8 & 21 & 20.3 & 16 & 22.6 & 28.1 \\
\hline $\mathbf{N i}$ & 29 & 6 & 6 & 27 & 13 & 58 & 22 & 14 & 21 & 19 & 18 & $42 \quad 0$ \\
\hline Pr & 5.24 & 4.06 & 4.67 & 5.17 & 9.43 & 5.28 & 5.63 & 4.98 & 4.66 & 4 & 5.27 & 6.63 \\
\hline $\mathbf{R b}$ & 8.3 & 33 & 23.4 & 16.1 & 73.1 & 16.7 & 29.2 & 11.9 & 10.3 & 26.4 & 24.6 & 2.7 \\
\hline Sm & 5.3 & 3.7 & 4 & 5.5 & 8.5 & 5.1 & 4.9 & 5.9 & 5.7 & 3.8 & 5.8 & 8 \\
\hline Sn & 1 & 1 & 1 & 1 & 3 & 2 & 1 & 2 & 2 & 1 & 2 & 2 \\
\hline Ta & 0.5 & 0.5 & 0.5 & 0.5 & 0.8 & 0.5 & 0.6 & 0.6 & 0.5 & 0.5 & 0.5 & 0.5 \\
\hline $\mathbf{T b}$ & 1.01 & 0.71 & 0.58 & 0.97 & 1.44 & 0.95 & 0.92 & 1.1 & 1.08 & 0.7 & 1.07 & 1.57 \\
\hline Th & 2.7 & 4.1 & 6.5 & 2.6 & 6.2 & 3.8 & 6 & 4.6 & 4.6 & 2.3 & 4.2 & 4.3 \\
\hline TI & 0.5 & 0.5 & 0.5 & 0.5 & 0.5 & 0.5 & 0.5 & 0.5 & 0.5 & 0.5 & 0.5 & 0.5 \\
\hline $\mathbf{T m}$ & 0.5 & 0.39 & 0.35 & 0.49 & 0.66 & 0.41 & 0.47 & 0.47 & 0.53 & 0.33 & 0.48 & 0.88 \\
\hline $\mathbf{U}$ & 0.77 & 0.85 & 2.55 & 0.7 & 1.77 & 1.08 & 1.97 & 2.17 & 2.37 & 1.33 & 1.52 & 6.12 \\
\hline V & 235 & 91 & 17 & 221 & 251 & 188 & 163 & 159 & 185 & 164 & 207 & 223 \\
\hline $\mathbf{W}$ & 1 & 1 & 1 & 1 & 1 & 1 & 1 & 1 & 1 & 1 & 1 & 1 \\
\hline $\mathbf{Y}$ & 35.1 & 27.7 & 25.2 & 33.6 & 52.1 & 34.2 & 32.1 & 37.8 & 39 & 24.2 & 36.80 & 59.8 \\
\hline $\mathbf{Y b}$ & 3.4 & 2.8 & 2.5 & 3.3 & 4.5 & 3.2 & 3.1 & 3.4 & 3.7 & 2.3 & 3.2 & 5.9 \\
\hline
\end{tabular}


Table 2 Whole-rock major, trace and rare earth element (REE) analyses of representative rock samples from the basaltic rocks. Major (wt. \%) and trace element (ppm) compositions.

\begin{tabular}{|c|c|c|c|c|c|c|c|c|}
\hline & Basalt & & & Diabasic & & & & \\
\hline Sample & B.1 & N.K.1 & N.K.3 & P.1 & P.2 & P.3 & P.4 & N.K.4 \\
\hline $\mathrm{SiO}_{2}(\% \mathrm{wt})$ & 44.7 & 52.7 & 43.5 & 47.2 & 48.3 & 51.3 & 48.3 & 48.2 \\
\hline $\mathrm{TiO}_{2}$ & 1.62 & 1.7 & 1.44 & 1.65 & 1.82 & 2.08 & 1.84 & 1.98 \\
\hline $\mathrm{Al}_{2} \mathrm{O}_{3}$ & 17.7 & 15.8 & 15 & 16.1 & 15.8 & 15 & 15 & 14.6 \\
\hline $\mathrm{Fe}_{2} \mathrm{O}_{3}$ & 12.1 & 9.5 & 10.5 & 8.96 & 9.59 & 11.2 & 9.73 & 10.1 \\
\hline $\mathrm{Cr}_{2} \mathrm{O}_{3}$ & 0.05 & 0.01 & 0.09 & 0.04 & 0.03 & 0.01 & 0.03 & 0.02 \\
\hline MnO & 0.48 & 0.15 & 0.16 & 0.18 & 0.16 & 0.22 & 0.15 & 0.19 \\
\hline MgO & 3.95 & 3.28 & 6.07 & 7.11 & 7.11 & 2.7 & 7.38 & 5.72 \\
\hline $\mathrm{CaO}$ & 10.1 & 5.29 & 12.6 & 10.8 & 9.8 & 6.49 & 8.69 & 8.87 \\
\hline $\mathrm{Na}_{2} \mathrm{O}$ & 3.1 & 5.70 & 3.8 & 3.8 & 4.4 & 4.4 & 4.8 & 5.4 \\
\hline $\mathrm{K}_{2} \mathrm{O}$ & 0.3 & 1.25 & 0.26 & 0.12 & 0.19 & 2.56 & 0.11 & 0.85 \\
\hline $\mathrm{P}_{2} \mathrm{O}_{5}$ & 0.37 & 0.59 & 0.19 & 0.22 & 0.28 & 0.75 & 0.3 & 0.3 \\
\hline LOI & 6.07 & 3.59 & 7.37 & 5.66 & 3.75 & 3.72 & 4.74 & 4.75 \\
\hline Total & 101 & 99.6 & 100.9 & 101.8 & 101.3 & 100.4 & 101 & 101 \\
\hline Ba (ppm) & 340 & 130 & 40 & 20 & 30 & 150 & 20 & 70 \\
\hline $\mathrm{Sr}$ & 210 & 180 & 620 & 260 & 220 & 110 & 200 & 110 \\
\hline $\mathbf{Y}$ & 40 & 60 & 30 & 30 & 40 & 100 & 30 & 40 \\
\hline $\mathbf{Z n}$ & 146 & 116 & 75 & 64 & 77 & 165 & 82 & 90 \\
\hline $\mathbf{Z r}$ & 106 & 338 & 92.9 & 131 & 158 & 638 & 160 & 176 \\
\hline $\mathbf{A g}$ & 1 & 1 & 1 & 1 & 1 & 1 & 1 & 1 \\
\hline $\mathrm{Ce}$ & 17.7 & 49.2 & 13.8 & 17.9 & 19.6 & 73.9 & 21.2 & 22.3 \\
\hline Co & 37.9 & 18.9 & 38.6 & 30.5 & 30.2 & 15.8 & 30.3 & 31.3 \\
\hline Cs & 0.3 & 0.1 & 0.1 & 0.2 & 0.2 & 0.1 & 0.1 & 0.6 \\
\hline $\mathbf{C u}$ & 39 & 59 & 46 & 77 & 71 & 44 & 58 & 54 \\
\hline Dy & 5.91 & 9.72 & 4.62 & 4.85 & 5.82 & 15.9 & 5.5 & 6.11 \\
\hline Er & 3.76 & 6.16 & 2.96 & 3.11 & 3.53 & 10.4 & 3.42 & 4.01 \\
\hline Eu & 1.44 & 2.18 & 1.07 & 1.41 & 1.52 & 3.1 & 1.51 & 1.67 \\
\hline Ga & 18 & 18 & 17 & 15 & 16 & 24 & 16 & 17 \\
\hline Gd & 5.78 & 9.76 & 4.2 & 4.5 & 5.67 & 14.6 & 5.39 & 5.97 \\
\hline Hf & 3 & 8 & 2 & 3 & 4 & 15 & 4 & 4 \\
\hline Нo & 1.24 & 2.13 & 1.03 & 1.1 & 1.28 & 3.56 & 1.13 & 1.34 \\
\hline La & 9.4 & 20.7 & 6.4 & 7.9 & 7.70 & 29.2 & 8.9 & 8.80 \\
\hline Lu & 0.59 & 0.92 & 0.45 & 0.57 & 0.55 & 1.59 & 0.55 & 0.58 \\
\hline Mo & 2 & 2 & 2 & 2 & 2 & 2 & 2 & 2 \\
\hline Nb & 5 & 12 & 5 & 5 & 6 & 19 & 7 & 6 \\
\hline Nd & 12.7 & 29.2 & 9.8 & 11.9 & 13.5 & 42.9 & 13.9 & 15.2 \\
\hline $\mathrm{Ni}$ & 97 & 32 & 122 & 71 & 76 & 6 & 87 & 83 \\
\hline Pr & 2.97 & 6.89 & 1.99 & 2.69 & 2.94 & 10.6 & 3.04 & 3.31 \\
\hline $\mathbf{R b}$ & 7.4 & 15.3 & 6.4 & 1.5 & 2.7 & 28.9 & 2 & 13.8 \\
\hline Sm & 3.8 & 7.5 & 3.2 & 3.4 & 4 & 11.5 & 3.9 & 4.4 \\
\hline Sn & 1 & 5 & 1 & 1 & 2 & 9 & 2 & 3 \\
\hline Ta & 0.5 & 0.6 & 0.5 & 0.5 & 0.5 & 1.2 & 0.5 & 0.5 \\
\hline Tb & 0.96 & 1.52 & 0.68 & 0.75 & 0.86 & 2.4 & 0.85 & 1.03 \\
\hline Th & 1.1 & 3.3 & 0.9 & 1.3 & 0.9 & 5.4 & 0.7 & 0.9 \\
\hline $\mathrm{Tl}$ & 0.5 & 0.5 & 0.5 & 0.5 & 0.5 & 0.5 & 0.5 & 0.5 \\
\hline Tm & 0.54 & 0.86 & 0.4 & 0.43 & 0.48 & 1.56 & 0.44 & 0.56 \\
\hline $\mathbf{U}$ & 1.15 & 0.94 & 0.57 & 1.18 & 0.33 & 1.75 & 0.29 & 0.46 \\
\hline $\mathbf{V}$ & 269 & 125 & 226 & 206 & 210 & 90 & 199 & 205 \\
\hline $\mathbf{W}$ & 1 & 1 & 1 & 1 & 1 & 1 & 1 & 1 \\
\hline$Y$ & 35.9 & 58.7 & 28.7 & 29.6 & 34.6 & 96.7 & 32.5 & 38.2 \\
\hline Yb & 3.5 & 6.1 & 2.8 & 3 & 3.3 & 10.7 & 3.2 & 3.7 \\
\hline
\end{tabular}

2011; Shafaii Moghadam et al., 2012). The N.K.1 sample show more enrichment in elements and show negative Eu anomaly. This implies plagioclase accumulation in the early stage of magma evolution (Wilson, 1989). The REE geochemistry and normalizes trends of these basalts resembles those of the volcanic arc basalts within the Neo-Tethys Ocean.
Primitive mantle normalized incompatible trace element patterns for andesite rocks from the Noorabad region are shown in Figure 8A. These pattern shows that the LILE (Th, Pb, Rb, K, Cs) are strongly inclined, which is defined by high ratios of $\mathrm{Th}_{(\mathrm{n})} / \mathrm{La}_{(\mathrm{n})}=1.2-2.8$. The negative anomaly of $\mathrm{Sr}$ and $\mathrm{Ba}$ is in relation to their mobility during alteration. However, HFSE show 

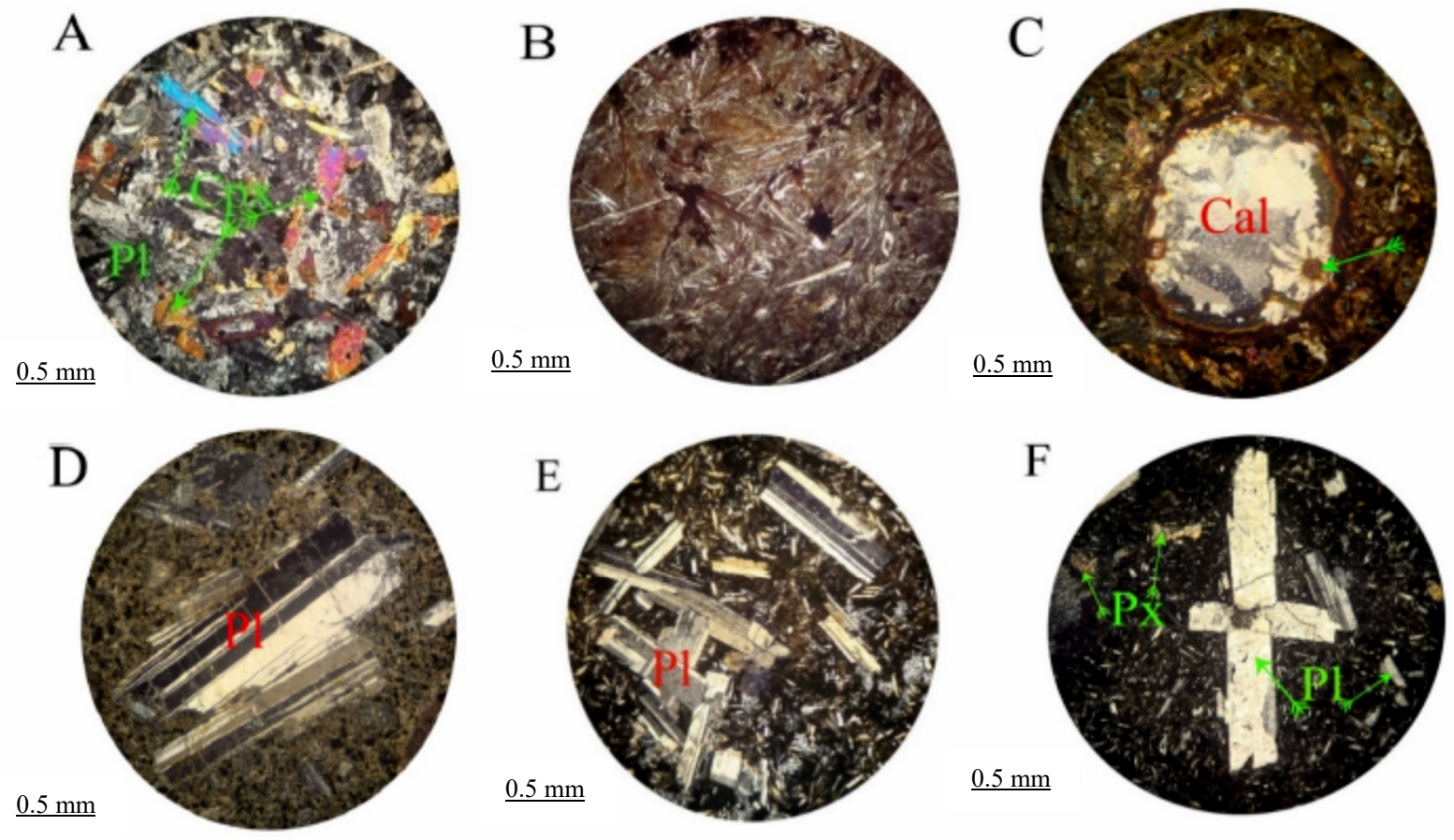

Fig. 4 A) Intergranular texture in diabase dikes. B) Microlithic texture in basaltic rocks, fine plagioclase set in the cryptocrystalline matrix. C) Amygdalin texture from filling of cavity with calcite and iron oxide. D) porphyry texture in andesite rocks. E, F) Glomeroporphyry texture from aggregation of plagioclase crystal in the microlith-rich matrix.

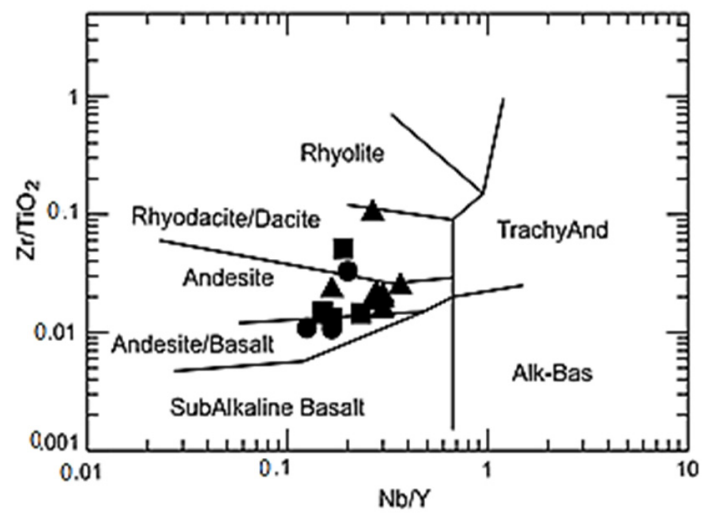

Fig. $5 \mathrm{Nb} / \mathrm{Y}$ versus $\mathrm{Zr} / \mathrm{TiO}_{2}$ binary diagram for classification studied volcanic rocks (the studied samples shown with triangle for andesite, square for diabasic and circle for basalts) (Winchester and Floyd, 1977).
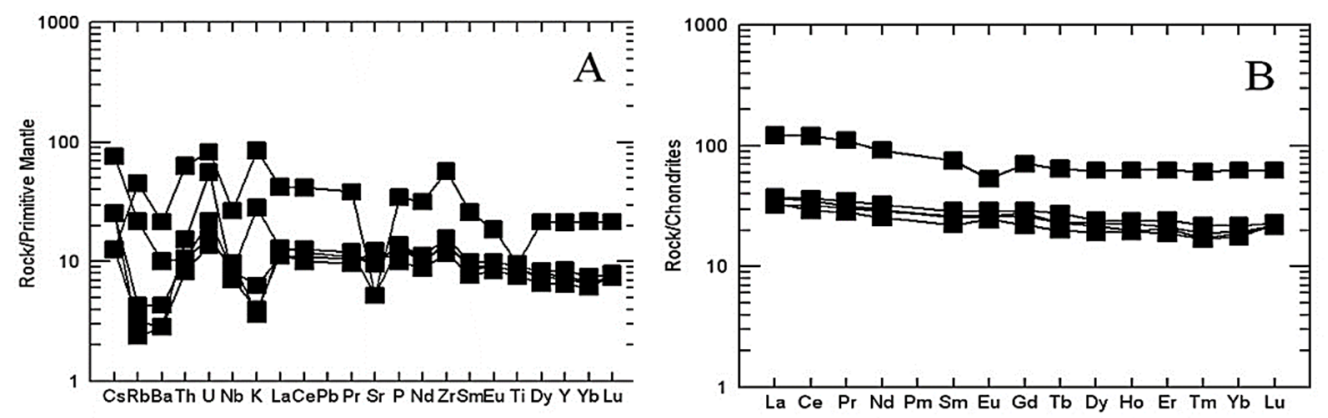

Fig. 6 A) Primary Mantle-normalized spider diagrams for the diabasic dikes from the Noorabad ophiolite (normalizing values are from Sun and McDonough, 1989). B) Chondrite-normalized rare earth elements for diabasic dike of the study area (Sun and Mc Donough, 1989). 

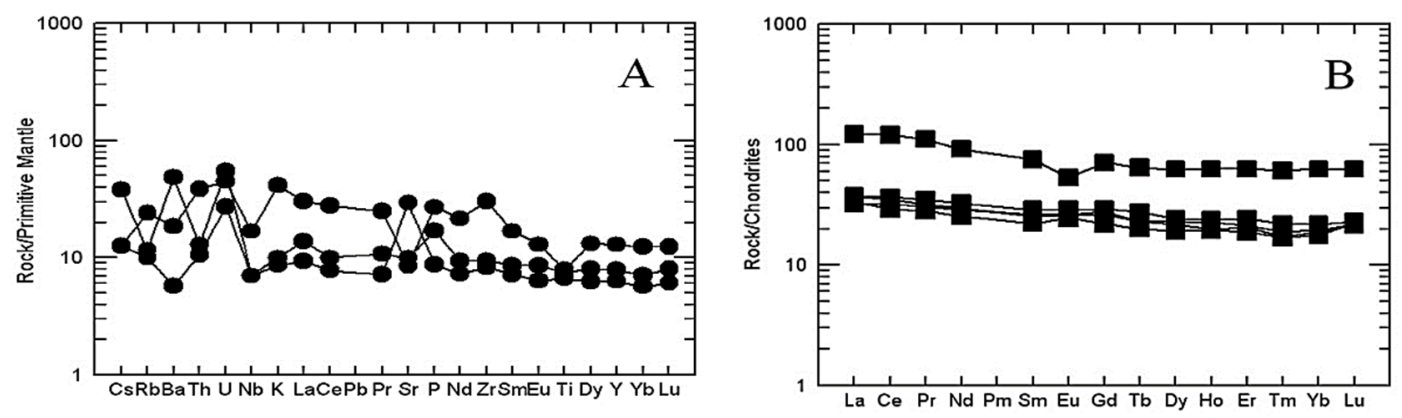

Fig. 7 A) Primary Mantle-normalized spider diagrams for the basaltic rocks from the Noorabad ophiolite (normalizing values are from Sun and McDonough, 1989). B) Chondrite-normalized rare earth elements for basaltic rocks of the study area (Sun and Mc Donough, 1989).
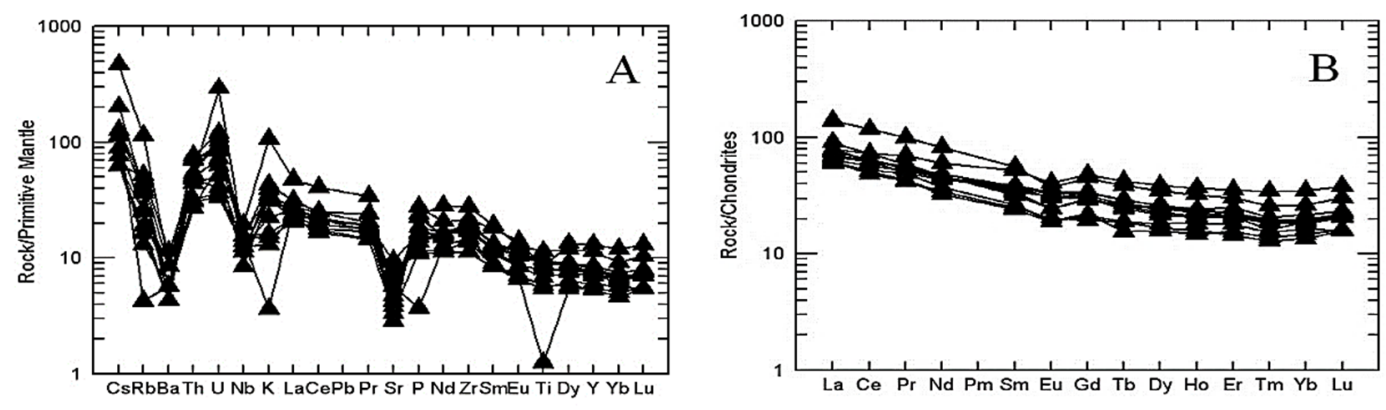

Fig. 8 A) Primary Mantle-normalized spider diagrams for the andesitic rocks from the Noorabad ophiolite (normalizing values are from Sun and McDonough, 1989). B) Chondrite-normalized rare earth elements for andesitic rocks of the study area (Sun and Mc Donough, 1989).

depletion $\quad\left(\mathrm{Nb}_{(\mathrm{n})} / \mathrm{La}_{(\mathrm{n})}=0.39-0.75\right) \quad$ with negative anomaly in the $\mathrm{Zr}, \mathrm{Nb}$ and $\mathrm{Ti}$ (Fig. 8A). The negative anomaly of $\mathrm{Nb}$ and enrichment in the LILE to HFSE is a characteristic feature of subduction related arc andesites (Kelemen et al., 1993). The chonderite normalized pattern for studied andesite rocks shows relative enrichment in the LREE respect to HREE $\left(\mathrm{La}_{(\mathrm{n})} / \mathrm{Yb}_{(\mathrm{n})}=2.3-5.4\right)$. In the chondrite-normalized REE diagrams, studied samples are characterized by enrichment in light rare-earth elements (LREE) relative to heavy rare earth elements (HREE) similar to subduction zone related magmas (Fig. 8B). The REE patterns are characterized by obvious negative $\mathrm{Eu}$ anomalies and uniform normalized patterns dikes which can be originated from homogenized source.

\section{PETROGENESIS AND TECTONIC SETTING OF STUDIED VOLCANIC ROCKS}

According to the pattern of REE and trace elements, the studied volcanic rocks, have predominantly calc-alkaline properties and are associated with a subduction zone. In addition, in the Th-Zr-Nb ternary diagram (Wood, 1980), the studied samples fall in the fields of N-MORB and mostly in subduction related basalts (Fig. 9A). In the Nb-Zr-Y (Meschede, 1986) ternary diagram, most of studied volcanic rock fall in within-plate tholeiites (for $\mathrm{C}$ ) and $\mathrm{N}-M O R B$ (for D) (Fig. 9B). In the $\mathrm{Th} / \mathrm{Yb}$ versus $\mathrm{Ta} / \mathrm{Yb}$ binary diagram (Pearce, 1983), studied samples plot as basalts with shoshonitic, calc-alcaline, tholeiitic (Fig. 10). The $\mathrm{Th} / \mathrm{Yb}$ ratio in this diagram is a good indicator for the segregation of Samples associated with subduction zone, from other environments. Because the increase in this ratio and higher location of the samples than mantel array, (N-MORB-OIB) is related to addition fluid phase, due subducted slab in generated magmas at subduction zone. Also, on the $\mathrm{Th} / \mathrm{Yb}$ versus $\mathrm{La} / \mathrm{Yb}$ discriminate diagram (Condie, 1989), is used to distinguish the different volcanic arc, Noorabad volcanic rocks plot in the fields for islands arc within ocean basalts (Fig. 11).

\section{TECTONIC MODEL OF NOORBAD OPHIOLITE}

Several tectonic events have been reported by researchers for Neo-Tethys Ocean (Berberian and King, 1981; Desmons and Beccaluva, 1983; Dercourt et al., 1986; Lippard et al., 1986; Glennie, 2000; Stampfli et al., 2001; Golonka, 2004; Agard et al., 2005; Robertson, 2007; Ghasemi and Talbot, 2005; Mohajjel et al., 2003) Which are essentially similar, but has different times (Allahyari et al., 2010). According to Mohajjel et al. (2003) tectonic evolution and genesis of Neo-Tethys Ocean was conducted in four stages:

1. Neo-Tethys ocean formation in Triassic;

2. Neo-Tethyan oceanic crust subduction along the northeast margin during the Jurassic-Miocene;

3. ophiolite obduction along the northeast margin of the Arabian Plate; in the Cretaceous, 

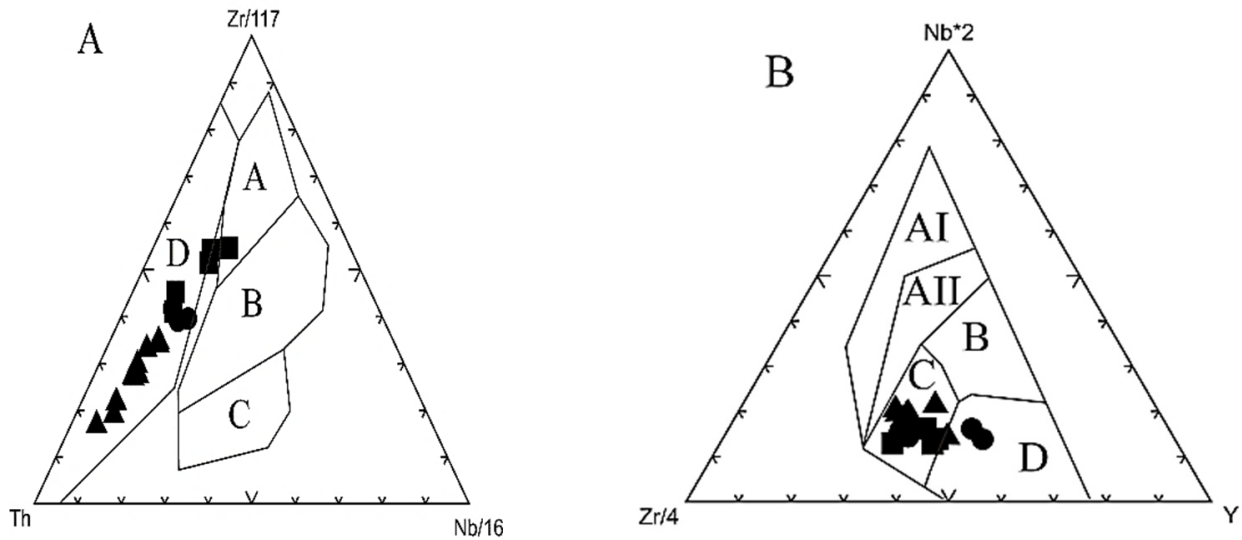

Fig. 9 A Triangular Th, $\mathrm{Zr}, \mathrm{Nb}$ diagram of Wood (1980). Samples of study area plot mainly in the $\mathrm{D}$ field or subduction zone basalts. A is field of N-MORB basalts, B the field of E-MORB and within plate tholeittes, $\mathrm{C}$ is the field of within plate alkaline basalts, $\mathrm{D}$ is subduction zone basalts. B The Zr-Nb-Y discriminate diagram of Meschede (1986) for volcanic rocks of Noorabad region Symbols as in Figure 5. The field are defined as follow: AI, within plate alkali basalts, AII, within plate alkali basalts and within plate tholeiites, B, E-type MORB, C, within-plate tholeiites and volcanic-arc basalts; D, N-type MORB and volcanic-arc basalts. Symbols as in Figure 5.

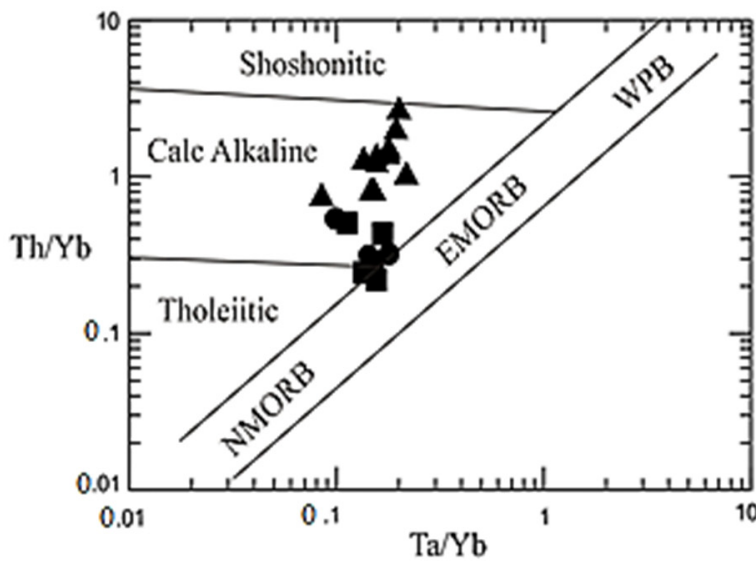

Fig. 10 The plotting of $\mathrm{Th} / \mathrm{Yb}$ versus $\mathrm{Ta} / \mathrm{Yb}$ diagram (Pearce, 1983) symbols as in Figure 5.

4. The collision Arabian Plate northeast margins with central Iran during the Miocene.

According to Stampfli et al. (2001) and Ghasemi and Talbot (2005), Neo-Tethys Ocean opening occurred Permian time but, (Lippard et al., 1986; Mohajjel et al., 2003; Agard et al., 2005; Allahyari et al., 2010) believed that this opening has occurred during the Triassic (Fig. 12A). According to geological dvidence, Neo Tethys lithosphere in the early Jurassic (Dercourt et al., 1986) or the Middle Jurassic (Agard et al., 2005) subducted beneath the Iran margin. According to the ages determination carried out on Boroujerd granitoid plutons (Ahmadi Khalaji et al., 2007), Hamadan (Shabazi et al., 2010) and Aligoudarz (Esna-Ashari et al., 2012), the formation of this plutons belongs to Middle Jurassic, then can be said the Neo-Tethys oceanic crust subducted beneath the Iran margin at late Triassic-

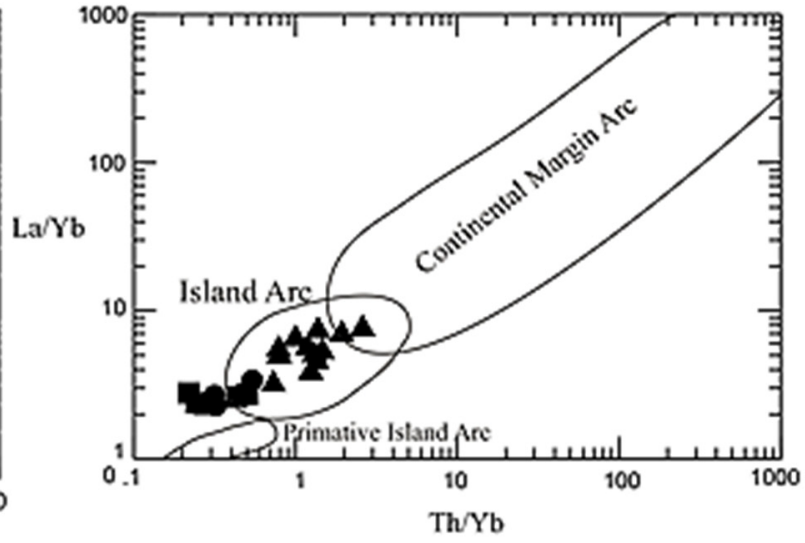

Fig. 11 Plot of $\mathrm{Th} / \mathrm{Yb}$ versus $\mathrm{La} / \mathrm{Yb}$ binary diagram (Condie, 1989) for studied volcanic rocks.

early Jurassic (compression phase of early Cimmerian) (Fig. 12B), and by melting the oceanic crust, mentioned granitoid plutons were formed and then emplacement in Sanandaj-Sirjan Zone (Fig. 12C). Dercourt et al. (1986) believes that in the time of subduction of oceanic crust under Iran, midoceanic ridge spreading zone is still present near the margin of Arabian block. Agard et al. (2005 )and Dercourt et al. (1986) suggested that Neo -Tethys ocean expansion like Iran and Oman ophiolite (Delaloye and Desmons, 1980; Knipper et al., 1986) continued until late Cretaceous. Desmons and Beccaluva (1983) and Dercourt et al. (1986) believed that the subduction zone within the Neo-Tethys Ocean, is located near the Arabian block margin at Late Cretaceous, but Ghasemi and Talbot (2005) know this subduction as belonging to the Cretaceous. Also, Agard et al. (2005) suggested that subduction within 

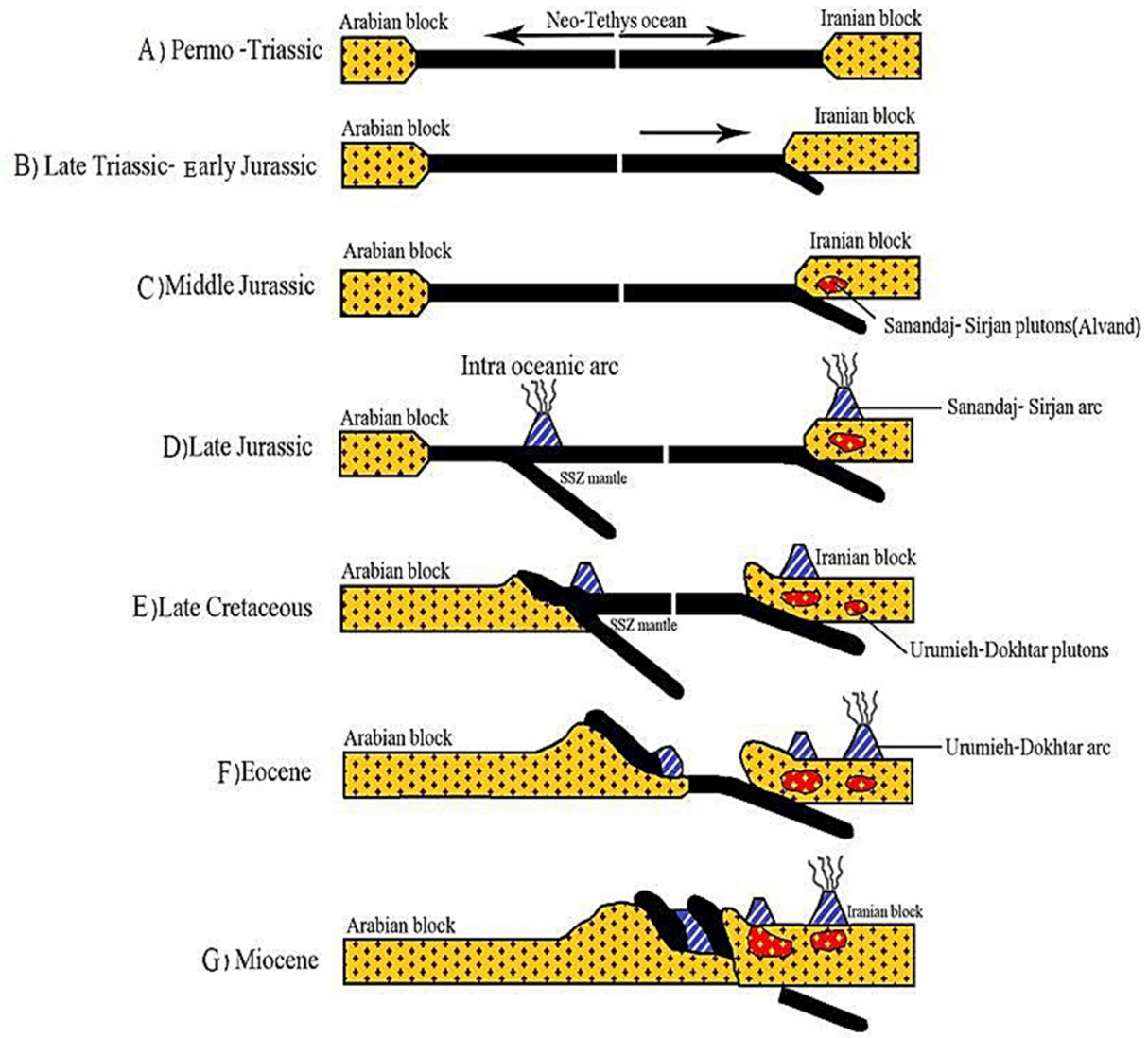

Fig. 12 Tectono - magmatic schematic model of Noorabad ophiolite and surrounding areas. A) Opening during the Triassic, B) The late Triassic to early Jurassic subduction, C) Subduction of oceanic crust under Iran and mid-oceanic ridge extend areas, D) intra oceanic subduction in the Late Jurassic, E) Urmia-Dokhtar zone plutons as a result of Neo-Tethyan oceanic crust subducting under Iran, F) Peak magmatism activity (volcanic-plutonic) of Urmia-Dokhtar zone, G) Start time of collision between Arabia and Iran in Oligocene.

oceanic occurred in the early Cretaceous. Due to the evidence of volcanic, available unconformity and located of limestone units Albian - Cenomanian age (Shahidi and Nazari, 1997) on the south-Noorabad Andesit, probably intraplate subduction occurred the late Jurassic (late Cimmerian) (Fig. 12D). Berberian and King (1981) suggest that Andes magmatism at Iran margin (Sanandaj-Sirjan zone) occurred at this time (Fig. 12D).

There is consensus about Arabian block margin collision with intra ocean arc, and all previous researchers have attributed this collision to the late Cretaceous (Laramide phase) (Fig. 12E). At this time Urmia-Dokhtar zone plutons, are emplacement due to more subduction of Neo-Tethyan oceanic crust beneath the Iran margin, but Shafaii Moghadam et al. (2009) believed Magmatism (intrusive and volcanic rocks) in this zone belong to the Eocene-Miocene, that occurred after the closure of Naein-Baft ocean, and occurred due to Neo-Tethyan oceanic crust subducting under Iran (Fig. 12E). Given that peridotite plutons at Aleshtar-Kermanshah axis ophiolites covered by Oligo-Miocene pelagic limestones belong to warm and marginal sea (Kiani, 2011), can say that no collision between Iran and Arabian block, it happend during the Eocene-Miocene. At this time magmatic activity (plutonic-volcanic) reached its peak at Urmia -Dokhtar zone, and granitic pluton such as Marvak (north Doroud city) been emplacement in SanandajSirjan (Kiani, 2011) (Fig. 12F). Some researchers (Ghasemi and Talbot, 2005) considered that, the collision between Iran and Arabian is belonging to the middle Eocene, but Agard et al. (2005) attributed the beginning of the collision the Oligocene that continued to Pliocene. Mohajjel et al. (2003) believes that this collision is belonging to the Miocene, and Allahyari et al. (2010) suggest that collision started at Oligocene that continues to the present (Fig. 12G). In general, determined, as the diagrams of the chondrite normalized REE and trace elements is normalized to the primitive mantle, volcanic rocks of Noorabad ophiolite, show calc-alkaline characteristics by depletion of HFSE and enrichment of LREE and LILE. These characteristics are similar to other Tethyan ophiolite that outcrops along the BitlisZagros Suture Zone, and their formation is associated with subduction zones. Kermanshah ophiolite age (similar to other ophiolite East Mediterranean-ZagrosOman) is considered $86.3 \pm 7.8$ and $81.4 \pm 3.8$ Ma by the K-Ar method (Delaloye and Desmons, 1980; Braud, 1970, 1987; Ghazi and Hassanipak, 1999). Geochemical characteristics of volcanic sequence in 
Kermanshah ophiolite complex, is considered, similar to series of island arc tholeiities and oceanic islands Basalt (OIB), with smaller amounts lava similer to MORB (Desmons and Beccaluva, 1983; Ghazi and Hassanipak, 1999). It seems that alkaline lavas type that mentioned by Ghazi and Hassanipak (1999) in Kermanshah ophiolite complex, not associated with the ophiolite complex, and related to the primary rift in the Permian, and has been sampled from basaltic sequence between Bisoton limestones. This alkaline basalt type is also seen in Neyriz of Iran and Havasina of Oman series (Triassic to Cretaceous), and related to Gondwana rifting in the early stages of Neotethys ocean formation. studies, suggested that pillow basalt and dikes in Kermanshah ophiolite complex, are toleiitic and calc-alkaline in nature and based on the tectonic discrimination diagrams are grouped in toleiitic to calc-alkaline basalts field of the island arc setting (Shafaii Moghadam and Stern, 2011; Tahmasbi et al., 2016; Kiani et al., 2019), and confirmed the results of this study.

\section{CONCLUSION}

1. The studied rocks of the Noorabad ophiolite mainly include diabasic dikes (dolorite, interagranular and poikilitic texture), basalt and andesite with porphyric texture.

2. Sercitic, propilitic and argilic are common alteration zones in this region, that Sercitic alteration has most extension.

3. Noorabad intermediate and mafic rocks are toleiitic and calc-alkaline in nature and based on the tectonic discrimination diagrams are grouped in toleiitic to calc-alkaline basalts field of the island arc setting. They display LREE enrichment and HREE depletion in the chonderite normalized diagrams.

4. Their geochemical characteristics are similar to other Tethyan ophiolite that outcrops along the Bitlis-Zagros-Suture Zone, and their formation is associated to the formation of an island arc in relation to an intra-oceanic subduction zone

5. Geochemical behaviour of elements by using various petrogenesis diagrams suggest that intermediate and mafic rocks of Kermanshah ophiolites in the Noorabad region were derived from homogenized mantle sources in the island arc setting wein the Neo-Tethys Ocean.

\section{REFERENCES}

Agard, P., Omrani, L., Jolivet, L. and Mouthereau, F.: 2005, Convergence history across Zagros (Iran): constraints from collisional and earlier deformation. Int. J. Earth Sci., 94, 401-419. DOI: 10.1007/s00531-005-0481-4

Ahmadi Khalaji, A., Esmaeily, D., Valizadeh, M.V. and Rahimpour-Bonab, H.: 2007, Petrology and geochemistry of the granitoid complex of Boroujerd, Sanandaj-Sirjan Zone, Western Iran. J. Asian Earth Sci., 29, 859-877. DOI: 10.1016/j.jseaes.2006.06.005

Ali, S.A. and Aswad, K.: 2013, SHRIMP U-Pb dating of zircon inheritance in Walash arcvolcanic rocks
(Paleogene age), Zagros Suture Zone, NE Iraq: new insights intocrustal contributions to trachytic andesite generation. Iraqi N. J. Earth Sci.,13, 1, $45-58$.

Ali, S.A., Buckman, S., Aswad, K.J., Jones, B.G., Ismail, S.A. and Nutman, A.P.: 2013, The tectonic evolution of a Neo-Tethyan (EoceneOligocene) island-arc (Walash and Naopurdan groups) in the Kurdistan region of the Northeast Iraqi Zagros Suture Zone. Island Arc, 22, 1, 104125. DOI: 10.1111/iar.1200a7

Allahyari, K., Saccan, E., Pourmoafi, M., Beccaluva, L. and Masoudi, F.: 2010, Petrology of mantle peridotites and intrusive mafic rocks from the Kermanshah Ophiolitic Complex (Zagros Belt, Iran): implications for the geodynamic evolution of the Neo-Tethyan oceanic branch between Arabia and Iran. Ofioliti, 35, 71-90.

Allahyari, K., Saccani, E., Rahimzadeh, B. and Zeda, O.: 2014, Mineral chemistry andpetrology of highly magnessian ultramfic cumulates from the Sarve-Abad (Sawlava) ophiolites (Kurdistan, NW Iran): New evidence for boninitic magmatism in intra-oceanic fore-arc setting in the Neo-Tethys between Arabia and Iran. J. Asian Earth Sci., 79, 312-328. DOI: $10.1017 / \mathrm{S} 0016756818000201$

Ao, S., Xiao, W., Khalatbari-Jafari, M., Talebian, M., Chen, L., Wan, B.W.J. and Zhang, Z.: 2016, U$\mathrm{Pb}$ zircon ages, field geology and geochemistry of the Kermanshah ophiolite (Iran): From continental rifting at $79 \mathrm{Ma}$ to oceanic core complex at ca. $36 \mathrm{Ma}$ in the southern NeoTethys. Gondwana Res., 31, 305-318. DOI: 10.1016/j.gr.2015.01.014

Arvin, M.: 1990, Petrology and geochemistry of ophiolites and associated rocks from the Zagros suture, Neyriz, Iran. In: J. Malpas, E.M. Moores, A. Panayiotou and Xenophontos, C. (Eds.), Ophiolites, oceanic crustal analogues. Proceedings of the Symposium "Troodos 1987". Geological Survey Department, Nicosia, Cyprus, 351-365.

Aswad, K.J., Al-Samman, A.H., Aziz, N.R. and Koyi, A.M.: 2014. The geochronology and petrogenesis of Walash volcanic rocks Mawat nappes: constraints on the evolution of the northwestern Zagros suture zone, Kurdistan Region, Iraq. Arab. J. Geosci., 7, 1403-1432.

Azizi, H. and Asahara, Y.: 2013, Juvenile granite in the Sanandaj-Sirjan zone, NW Iran:Llate JurassicEarly Cretaceous arc-continent collision. Int. Geol. Rev., 55, 1523-1540. DOI: $10.1080 / 00206814.2013 .782959$

Berberian, M. and King, G.C.P.: 1981, Towards a paleogeography and tectonic evolution of Iran. Can. J. Earth Sci., 18, 210-265. DOI: $10.1139 / \mathrm{e} 81-019$

Braud, J.: 1970, Les formations du Zagros dans la region de Kermanshah (Iran) et leurs rapports structuraux. Comptes Rendus l'Academie des Sciences., 271, 1241-4. DOI: $10.1017 / \mathrm{S} 0016756811000331 \mathrm{P}$

Condie, K.C.: 1989, Geochemical changes in basalts and andesites across the Archean-Proterozoic boundary: identification and significance. Lithos, 23, 1-18. DOI: 10.1016/0024-4937(89)90020-0 
Delaloye, M. and Desmons, J.: 1980, Ophiolites and mélange terranes in Iran: a geochronological study and its paleotectonic implications. Tectonophysics, 68, 83-111. DOI: 10.1016/0040-1951(80)90009-8

Dercourt, J., Zonenshian, L.P., Ricou, L.E., Kazmin, V.G., Le Pichon, X., Knipper, A. L., Grandjacquet, C., Sbortshikov, I.M., Geyssant, J., Lepvrier, C., Pechersky, D.H., Boulin, J., Sibuet, J.C., Savostin, L.A., Sorokhtin, O., Westphal, M., Bazhenov, M.L., Lauer, J.P.and Biju-Duval, B.: 1986, Geological evolution of the Tethys Belt from the Atlantic to the Pamirs since the Lias. Tectonophysics, 123, 241-315. DOI: 10.1016/j.gr.2017.07.013

Desmons, J. and Beccaluva, L.: 1983, Mid-ocean ridge and island arc affinities in ophiolites from Iran: palaeographic implications. Chemi. Geol., 39, 39-63. DOI: 10.1016/0009-2541(83)90071-2

Dilek, Y. and Delaloye, M.: 1992, Structure of the Kizildag ophiolite, a slow-spread Cretaceous ridge segment north of the Arabian promontory. Geology, 20, 19-22. DOI: $10.1130 / 0091-7613(1992) 020$

Dilek, Y., Thy, P., Hacker, B. and Grundvig, S.: 1999, Structure and petrology of Tauride ophiolites and mafic dike intrusions (Turkey): implications for the Neo-Tethyan ocean. Geol. Soc. Am. Bull., 111, 11921216. DOI: 10.1130/0016-7606(1999)111

Esna-Ashari, A., Tiepolo, M., Valizadeh, M.V., Hassanzadeh, J. and Sepahi, A.A.: 2012, Geochemistry and zircon U-Pb geochronology of Aligoodarz granitoid complex, Sanandaj-Sirjan Zone. Iran. J. Asian Earth Sci., 43, 11-22. DOI: 10.1016/j.jseaes.2011.09.001

Ghasemi, A. and Talbot, C.J.: 2006, A new tectonic scenario for the Sanandaj-Sirjan Zone (Iran). J. Asian Earth Sci., 26, 683-693. DOI: 10.1016/j.jscaed.2005.01.003

Ghazi, A.M. and Hassanipak, A.A.: 1999, Geochemistry of subalkaline and alkaline extrusives from the Kermanshah ophiolite, Zagros Suture Zone, western Iran: implications on Tethyan plate tectonics. J. Asian Earth Sci., 17, 319-332.

Glennie, K.W.: 2000, Cretaceous tectonic evolution of Arabia's eastern plate margin: a tale of two oceans, In: A.S. Alsharan and R.W. Scott (Eds.), Middle East models of Jurassic/Cretaceous carbonate systems. SEPM, Geological Society of London Special Publication, 69, 9-20.

Gill, J.B.: 1981, Orogenic andesites and plate tectonics. Springer, Berlin.

Golonka, J.: 2004, Plate tectonic evolution of the southern margin of Eurasia in the Mesozoic and Cenozoic. Tectonophysics, 381, 235-273. DOI: $10.1016 /$ j.tecto.2002.06.004

Hassanipak, A.A. and Ghazi, A.M.: 2000, Petrology, geochemistry and tectonic setting of the Khoy ophiolite, northwest Iran: implications for Tethyan tectonics. J. Asian Earth Sci., 18, 109-121.

DOI: 10.1016/S1367-9120(99)00023-1

Hébert, R., Huot, F., Wang, C. and Liu, Z.: 2003, Yarlung Zangbo ophiolites (Southern Tibet) revisited: geodynamic implications from the mineral record. In: Dilek, Y., Robinson, P.T. (Eds.), Ophiolites in Earth History. Geological Society of London Special Publication, 218, 165-190.

DOI: 10.1144/GSL.SP.2003.218.01.10

Kelemen, P.B., Shimizu, N. and Dunn, T.: 1993, Relative depletion of Niobium in some arc magmas and the continental crust: partitioning of $\mathrm{K}, \mathrm{Nb}, \mathrm{La}$ and $\mathrm{Ce}$ during melt/ rock reaction in the upper mantle. Earth Planet. Sci. Lett., 120, 111-134.

DOI: $10.1016 / 0012-821 X(93) 90234 \_Z$

Kiani, M.: 2011, Geochemistry, economic geology and petrogenesis of the ophiolite complex in the AlashtarKermanshah axis (in Persian). MSc thesis, Islamic Azad University, Khorramabad Branch, Iran.

Knipper, A., Ricou, L.E. and Dercourt, J.: 1986, Ophiolites as indicators of the geodynamic evolution of the Tethyan Ocean. Tectonophysics, 123, 213-240. DOI: $10.1016 / 0040-1951(86) 90198-8$

Lippard, S.J., Shelton, A.W. and Gass, I.G.: 1986, The ophiolite of Northern Oman. Geological Society London Memoir, 11, $178 \mathrm{pp}$.

Malpas, J., Zhou, M.-F., Robinson, P.T. and Reynolds, P.H.: 2003, Geochemical and geochronological constraints on the origin and emplacement of the Yarlung Zangbo ophiolites, Southern Tibet. In: Dilek, Y. and Robinson, P.T. (Eds.), Ophiolites in Earth History. Geological Society of London Special Publication, 218, 191-206. DOI: 10.1144/GSL.SP.2003.218.01.11

Meschede, M.: 1986, A method of discriminating between different types of mid-ocean ridge basalts and continental tholeiites with the $\mathrm{Nb}, \mathrm{Zr}, \mathrm{Y}$ diagram. Chem. Geol., 56, 207-218. DOI: $10.1016 / 0009-2541(86) 90004-5$

Mohajjel, M., Fergusson, C.L. and Sahandi, M.R.: 2003, Cretaceous-Tertiary convergence and continental collision, Sanandaj-Sirjan Zone, Western Iran. J. Asian Earth Sci., 21, 397-412. DOI: $10.1016 / \mathrm{S} 1367-9120(02) 00035-4$

Monnier, C., Girardeau, J., Maury, R.C. and Cotten, J.: 1995, Back-arc basin origin for the East Sulawesi ophiolite (eastern Indonesia). Geology, 23, 851-854. DOI: $10.1130 / 0091-7613(1995) 023$

Nouri, F., Azizi, H., Golonka, J., Asahara, Y., Orihashi, Y., Yamamoto, K., Tsuboi, M. and Anma, R.: 2016, Age and petrogenesis of Na-rich felsic rocks in western Iran: evidence for closure of the southern branch of the Neo-Tethys in the Late Cretaceous. Tectonophysics., 671, 151-172. DOI: 10.1017/S0016756818000201

Parlak, O., Hoeck, V., Kozlu, H. and Delaloye, M.: 2006, Oceanic crust generation in an island arc tectonic setting, SE Anatolian Orogenic Belt (Turkey). Geol. Mag., 141, 583-603. DOI: $10.1017 /$ S0016756804009458

Pearce, J.A.: 1982, Trace element characteristics of lavas from destructive plate boundaries. In: E.S. Thorpe (ed.), Andesites. Wiley, New York, 525-548.

Pearce, J.A.: 1983, Role of sub-continental lithosphere in magma genesis at active continental margins. In: C.J. Hawkesworth and M.L. Nurry (eds.), Continental Basalts and Mantle Xenoliths. Shiva, Nantwich, 230 249.

Pearce, J.A., Alabaster, T., Shelton, A.W. and Searle, M.P.: 1981, The Oman ophiolite as a Cretaceous arc-basin complex: evidence and implications. Philos. Trans. R. Soc. Lond., 300, 299-317.

Pearce, J.A., Lippard, S.J. and Roberts, S.: 1984, Characteristics and tectonic significance of suprasubduction zone ophiolites. In: Kokelaar, B.P., Howells, M.F. (Eds.), Marginal Basin Geology. Geological Society of London, Special Publication, $16,77-89$. 
Robertson, A.H.F.: 2007, Overview of tectonic settings related to the rifting and opening of Mesozoic ocean basins in the Eastern Tethys: Oman, Himalayas and Eastern Mediterranean regions. In Imaging, Mapping and Modeling Continental Lithosphere Extension and Breakup (eds. G. D. Karner, G. Manatschal and L. M. Pinheiro). Geological Society of London, Special Publication, no. 282, 325-388.

DOI: $10.1144 /$ SP282.15

Robinson, P.T. and Malpas, J.: 1990, The Troodos ophiolite of Cyprus: new perspectives on its origin and emplacement. In: J. Malpas, E.M. Moores, A. Panayiotou and C. Xenophontos (eds.), Ophiolites, Oceanic Crustal Analogues. Proceedings of the Symposium "Troodos 1987". The Geological Survey Department, Nicosia, Cyprus, 13-26.

Rolland, Y.: 2000, Middle Cretaceous back arc formation and arc evolution along the Asian margin. Tectonophysics, 325, 145-173.

DOI: 10.1016/S0040-1951(00)00135-9

Rollinson, H.R.: 1993, Using geochemical data: Evaluation, presentation, and interpretation. Longman Scientific and Technical, John Wiley \& Sons, New York.

Saccani, E., Allahyari, K., Beccaluva, L. and Bianchini, G.: 2013, Geochemistry and petrology of the Kermanshah ophiolites (Iran): implication for the interactionbetween passive rifting oceanic accretion, and OIB-type components in the Southern Neo-Tethys Ocean. Gondwana Res., 24, 392-411. DOI: $10.1016 /$ j.gr.2012.10.009

Saccani, E., Allahyari, K. and Rahimzadeh, B.: 2014, Petrology and geochemistry of mafic magmatic rocks from the Sarve-Abad ophiolites (Kurdistan region, Iran): evidence for interaction between MORB-type asthenosphere and OIB-type components in the southern Neo-Tethys Ocean. Tectonophysics, 621, 132-147. DOI: 10.1016/j.tecto.2014.02.011

Sarkarinejad, K.: 1994, Petrology and tectonic setting of the Neyriz ophiolite, southeast Iran. In: Ishiwatari, A., Malpas, J. and Ishizuka, H. (eds.) Circum-Pacific Ophiolites. Proceeding of the 29th International Geological Congress, 221-234.

Shafaii Moghadam, H. and Stern, R.: 2015, Ophiolites of Iran: keys to understanding thetectonic evolution of SW Asia: (II) Mesozoic ophiolites. J. Asian Earth Sci., 100, 31-56. DOI: 10.1016/j.jseaes.2014.12.016

Shafaii Moghadam, H. and Stern, R.J.: 2011, Geodynamic evolution of Upper Cretaceous Zagros ophiolites: formation of oceanic lithosphere above a nascent subduction zone. Geol. Mag., 148: 762-801. DOI: $10.1017 / \mathrm{S} 0016756811000410$

Shafaii Moghadam, H., Stern, R.J., Kimura, J.I., Hirahara, Y., Senda, R. and Miyazaki, T.: 2012, Hf-Nd isotopic constraints on the origins of Zagros ophiolites. Island Arc, 21, 202-214. DOI: $10.1111 / j .1440-1738.2012 .00815 . x$

Shafaii Moghadam, H., Whitechurch, H., Rahgoshay, M. and Monsef, I.: 2009, Significance of Nain-Baft ophiolitic belt (Iran): short-lived, transtensional Cretaceous back-arc oceanic basins over the Tethyan subduction zone. Comptes Rendus Geosci., 341, 1016-28. DOI: 10.1016/j.crte.2009.06.011
Shahbazi, H., Siebel, W., Pourmoafee, M., Ghorbani, M., Sepahi, A.A., Shang, C.K. and Vousoughi Abedini, M.: 2010, Geochemistry and U-Pb zircon geochronology of the Alvand plutonic complex in Sanandaj-Sirjan Zone (Iran): New evidence for Jurassic magmatism. J. Asian Earth Sci., 39, 668-683. DOI: 10.1016/j.jseaes.2010.04.014

Shahidi, M. and Nazari, H.: 1997, Geological map of Harsin, $1 / 100.000$ scale. Geological survey of Iran.

Shervais, J.W.: 1982, Ti-V plots and the petrogenesis of modern and ophiolitic lavas. Earth Planet. Sci. Lett., 59, 101-118. DOI: 10.1016/0012-821X(82)90120-0

Stampfli, G., Mosar, J., Faure, P., Pillevuit, A. and Vannay, J.C.: 2001, Permo-Mesozoic evolution of the western Tethys realm: the Neotethys East Mediterranean basin connection. In: P. Ziegler, W. Cacazza, A.H.F. Robertson and S. Crasquin-Soleau (Eds.), PeriTethyan rift/wrench basins and passive margins. Memories du Museum national d'histoire naturelle, 5, 51-108.

Staudigel, H., Plank, T., White, W.M. and Schmincke, H.: 1996, Geochemical fluxes during seafloor alteration of the upper oceanic crust: DSDP Sites 417 and 418. In: G.E. Bebout and S.H. Kirby (eds.), SUBCON: Subduction from Top to Bottom. Geophysical Monograph, American Geophysical Union, 96, 19-38. DOI: 10.1029/GM096p0019

Stocklin, J.: 1977, Structural correlation of the Alpine range between Iran and Central Asia. Mémoire Hors-Serie, Societé Geologique de France, 8, 333-353.

Sun, S.S. and McDonough, W.F.: 1989, Chemical and isotopic-systematics of oceanic basalts: implications for mantle composition and processes. Geological Society, Special Publications, 42, 313-345.

Tahmasbi. Z., Kiani. M. and Ahmadi Khalaji. A.: 2016, Petrology and geochemistry of diabasic dikes and andesitic- basaltic lavas in Noorabad- Harsin ophiolite, SE of Kermanshah, Iran. J. Earth Sci., 27, 6, 935-944. DOI: 10.1007/s12583-016-0686-4

Whitechurch, H., Omrani, J., Agard, P., Humbert, F., Montigny, R. and Jolivet, L.: 2013, Evidence for Paleocene-Eocene evolution of the foot of the Eurasian margin (Kermanshah ophiolite, SW Iran) from back-arc to arc: implications forregional geodynamics and obduction. Lithos, 182-183, 11-32. DOI: 10.1016/j.lithos.2013.07.017

Wilson, M.: 1989, Igneous Petrogenesis. Unwin Hyman, London.

Wood, D.A.: 1980, The application of a Th-Hf-Ta diagram to problems of tectonomagmatic classification and to establishing nature of basaltic lavas of the British Tertiary Volcanic Province. Earth and Planet. Sci. Lett., 50, 11-30. DOI: $10.1016 / 0012-821 \mathrm{X}(80) 90116-8$ 